\title{
Predation habits of octopus past and present and a new ichnospecies, Oichnus ovalis
}

\author{
RICHARD GRANVILLE BROMLEY
}

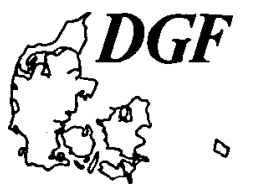

\begin{abstract}
Bromley, R. G.: Predation habits of octopus past and present and a new ichnospecies, Oichnus ovalis. Bull. geol. Soc. Denmark, Vol. 40, pp. 167-173, Copenhagen, June 3th, 1993. https://doi.org/10.37570/bgsd-1993-40-07

The geological history of octopus is virtually unknown, owing to lack of a preservable skeleton. Several octopod species today are known to drill holes in prey animals for the injection of venom. These borings are incipient trace fossils that have good fossilization potential, and are named Oichnus ovalis isp. nov. Their abundance in Pliocene assemblages suggests that they will be recognized elsewhere in Tertiary and perhaps older assemblages, providing greatly needed data on the earlier range and feeding habits of octopus.
\end{abstract}

Richard G. Bromley, Geologisk Institut, Øster Voldgade 10, DK-1350 København K, Denmark. December 31st 1992.

Tove Birkelund had a way with fossil cephalopods. She improved their taxonomy and used them efficiently in biostratigraphy. But she never studied their palaeoecology. The present paper deals with the palaeobiology of the octopus, a cephalopod that is thoroughly neglected by palaeontologists, because, having no skeleton, it is virtually unrepresented by body fossils.

Today, species of several genera of octopus occupy the summit of the trophic pyramid as top carnivore of marine benthic communities throughout the world's seas and oceans. Thus it follows that they must have had a long and similarly glorious past together with their close but well documented relatives the belemnoids. But we know only two species of bodily preserved fossil octopods. There are three well-preserved specimens of the early Late Cretaceous Palaeoctopus newboldi (Woodward 1896; Roger 1944, 1946) and a specimen from the Mississippian Mazon Creek fossil Lagerstätte, that represents a poorly preserved, "blob-like" coleoid, possibly an octopus (Solem \& Richardson 1975).

This non-preservation paradox led Teichert (1967) to suggest an unlikely evolutionary radiation (Fig. 1) whereby all eight extant families of octopods were shown as having originated in the Quaternary! In general, however, the Octopoda show many primitive characters that indicate that the order evolved from early teuthid (squid) stock at the beginning of the Mesozoic (Donovan
1964; Jeletzky 1965, 1966). The Mazon Creek example may indicate an even earlier origin.

There is a possible route by which to circumvent this impasse. At least some species of octopods today bore tiny holes in skeleton-bearing prey in order to paralyze them. These small holes, incipient trace fossils, should also be eminently recognizable in geological material. After all, drill-holes produced by predatory gastropods are a popular subject for palaeosynecological research and support a truly enormous literature. The corresponding literature on fossil octopus drill-holes is virtually non-existent.

Octopods are larger, drill faster, and make more holes than most predatory gastropods. Therefore their trace fossils should be the better known, not unknown. The present article hopefully will begin to relieve this imbalance.

Trace fossils frighten most geologists. Many palaeontologists insist that, when properly understood, each type should be ascribable to exact animal progenitors (Melville 1979). Many ichnologists insist, on the contrary, that they may never be so related to biological taxa (Bromley \& Fürsich 1980; Bromley 1990).

The present study should therefore be unsatisfactory to both parties. For while, on the one hand, octopods today make a variety of drill-hole morphologies in different prey species, on the other hand, only one of these boring styles is truly characteristic of octopus predation. This is a 


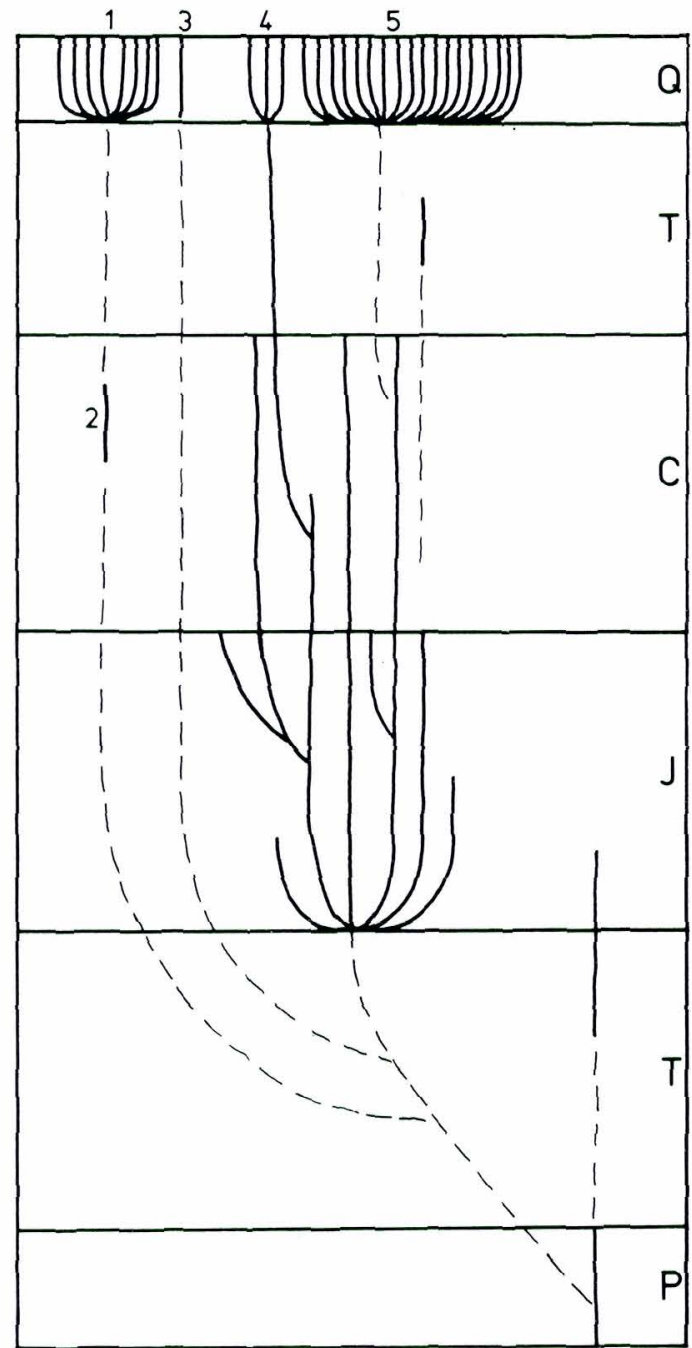

Fig. 1. An unlikely pattern of octopus and squid evolution from Permian to today, as envisaged by Teichert (1967). Octopoda 1, the 8 extant families of octopods; 2, Palaeoctopodidae. Teuthida - 3, Vampyroteuthididae; 4, families of Myopsina; 5, families of Oegopsina. Modified after Teichert (1967, Fig. 20), where details of the fossil lineages may be sought.

form that has been recognized in shells of the same prey species of Pliocene and Pleistocene age and is named Oichnus ovalis herein. It should be noted, however, that while this trace fossil does not alone represent the drill-hole of octopods, it is nevertheless $a$ drill-hole of octopods because no other taxon seems to be making such holes today.

\section{Boring activity of octopods}

After the first observation of octopus drilling predation (in oysters) was made by Fujita (1916), the habit was forgotten until rediscovered by Pilson \& Taylor (1961). The species in both cases was Octopus vulgaris. Carter (1968), Arnold \& Arnold (1969) and Wodinsky (1969) added further examples of drilling activity in this species. Rather naturally, these authors assumed that the radula was used as the boring tool, as in the drilling predatory snails. However, the elegant work of Marion Nixon has shown that the octopus bores molluse shells not with its radula, which is too broad for the hole, but with the salivary papilla, which is supplied with horny thorns for the purpose (Nixon 1977, 1979a, 1979b, 1980; Nixon \& Maconnachie 1988; Nixon et al. 1980). Crabs also are drilled in the same way (Guerra \& Nixon 1987).

There is evidence that the physical penetration of the skeleton is assisted by chemical secretions also (Nixon \& Boyle 1982; Nixon \& Maconnachie 1988; Ambrose et al. 1988).

Eventually, other species also were found to drill prey: Octopus cyanea in nautilus (Arnold

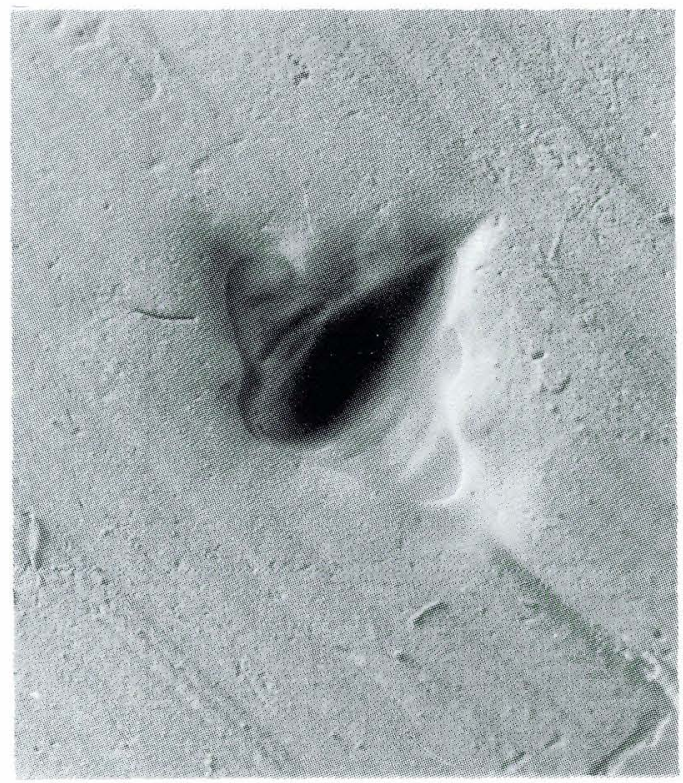

Fig. 2. A common form of octopus boring as found in shells of pearly nautilus. In this example, the prey has apparently been rotated 90 degrees after initiation of boring, producing a crossshaped bevel. The substrate is an adult Nautilus pompillius that was washed up as an empty shell on the Australian coast at Brisbane, Queensland. MGUH 22054. × 10 . 

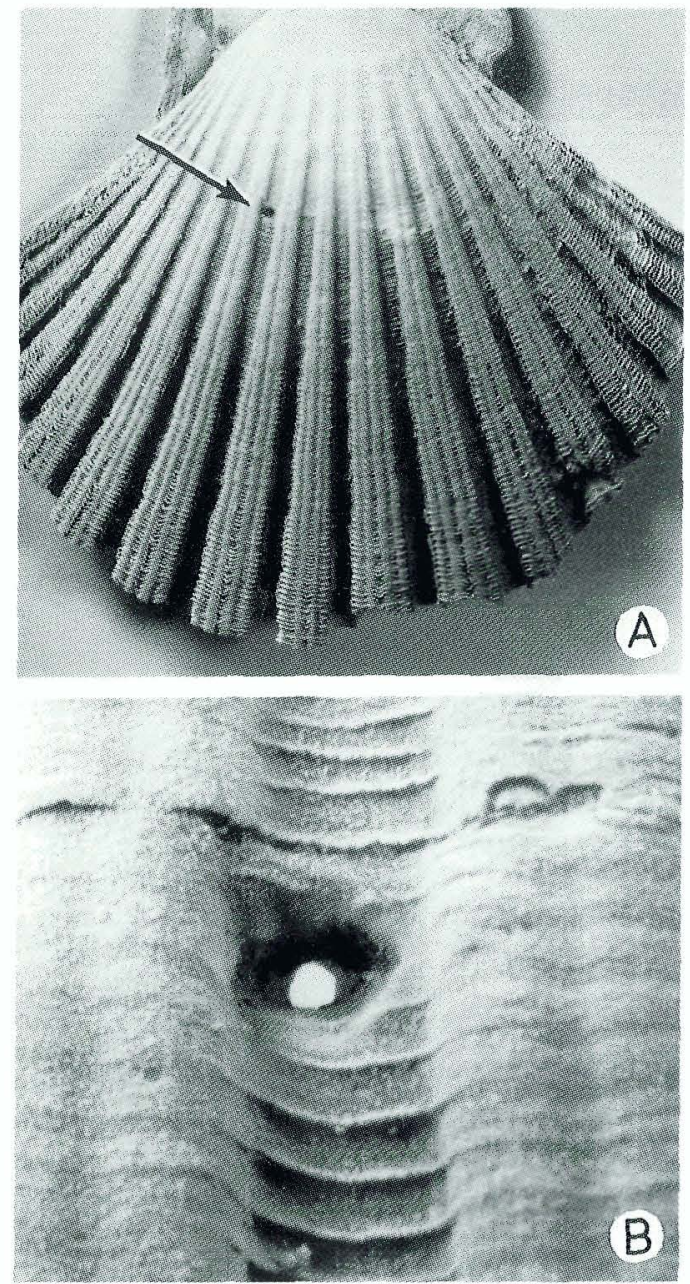

Fig. 3. A characteristic oval octopus penetration through the vaulted shell valve of Pecten jacobaeus, uppermost Pliocene, St. Paul's Bay, Lindos, Rhodes, Greece. MGUH 22055. A: location of the hole (arrow) is over the adductor muscle. $\times 2$. B: close-up $\times 20$.

1985) (Fig. 2); O. dolfeini in bivalves (Ambrose et al. 1988): and Eledone cirrhosa in crabs and barnacles (Boyle \& Knobloch 1981; Nixon \& Boyle 1982). Very few species as yet have been investigated, however, and the boring habit may prove to be widespread within octopods.

\section{Drilling mechanism}

The purpose of octopus in drilling its prey is not, as in predaceous gastropods, to eat the animal through the hole, but merely to inject poison (e.g., Pilson \& Taylor 1961). When it is relaxed, a bivalve may be opened, a snail extracted or a crab subdued. For this reason the holes are generally much smaller than gastropod predation holes, despite the generally larger size of the predator.

Drilling also proceeds relatively rapidly: an octopus may capture, kill and discard the cleaned valves of a large scallop all within $1 \frac{1}{2}$ hours (Nixon \& Maconnachie 1988). Because drilling is so rapid, an octopus commonly drills two holes or more in the same prey, in order to speed the relaxation of the animal.

Predatory snails drill slowly, and commonly place the hole at a thin part of the skeleton where drilling is relatively easy (e.g., Ziegelmeier 1954). The octopus, on the other hand, normally chooses to inject venom into adductor muscles, commonly finding the spot with great precision and thereby displaying a remarkable knowledge of the anatomy of different species of prey. Arnold (1985), examining nautilus shells bored presumably by $O$. cyanea, found that holes proved fatal only where drilled over muscles.

$O$. bimaculatus and $O$. vulgaris produce accumulations of shells outside their shelters (Ambrose 1983) and from these middens the natural prey species may be examined. In Greek coastal waters, $O$. vulgaris particularly favours Haliotis lamellosa as a prey. This archaeogastropod is never drilled, however, as the shell already possesses exhalent openings for use by the octopus. Likewise, gaping bivalves, such as Solecurtus strigilatus, which is commonly eaten by $O$. vulgaris, never is bored.

\section{Morphology of the boring}

Several authors have remarked that octopus drillholes are variable in shape (e.g., Wodinsky 1969; Bromley 1970). However, the detailed work of Nixon et al. (1980) and Nixon \& Maconnachie (1988) has shown that there is a certain correlation between hole shape and prey species. For example, $O$. vulgaris produces a highly characteristic, oval, tapering hole in shells of Mytilus edulis, M. galloprovincialis and Pecten jacobeus (Fig. 3), whereas a somewhat cylindrical hole is made in gastropods in general.

The characteristic oval boring is not made by 

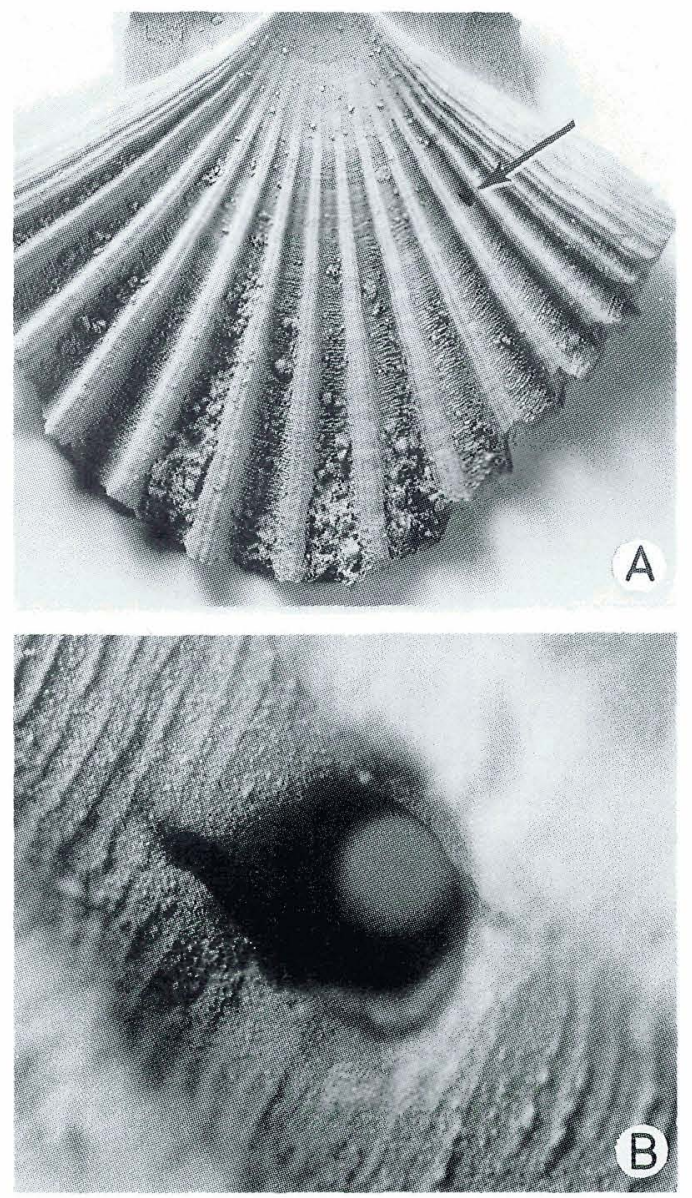

Fig. 4. A characteristic rounded oval boring in the flat valve of a Pecten jacobaeus from the Pliocene of Rhodes, Greece, $10 \mathrm{~m}$ below the top of the Kritika Formation at Kritika. MGUH 22056. A: the penetration (arrow) is located close to the adductor muscle (a near miss). Slightly enlarged. B: close-up, $\times 20$. Note the gutter leading into the boring at left. The inner aperture is larger than in strictly oval borings.

$O$. vulgaris alone, however. Those made by $O$. cyanea in nautilus are identical (Fig. 2), as are those of Eledone cirrhosa in crabs. It is possible that the oval penetration occurs where the octopus is unable to rotate its prey while drilling, owing to its ungainly size or shape; in Mytilus spp. the hole tends to be placed in the umbo, right at the end of the shell. The cylindrical borings, on the other hand, tend to occur in smaller, handier substrates, which could be rotated during drilling by the octopus.

The oval holes commonly have a broad, scoopshaped bevel externally, and an arcuate deeper portion, the work having stopped immediately a minute inner penetration was achieved. The cy- lindrical holes normally have a rounded external edge and a slightly more irregular form than the predation holes produced by muricid gastropods and with which they easily might be confused (Carriker \& Yochelson 1968; Bromley 1981).

Commonly, also, a short groove or gutter may lead into the cylindrical hole of an octopus (Fig. 4), a feature that is not characteristic of muricid borings.

\section{Ichnotaxonomy}

The cylindrical penetrations of octopus resemble the ichnotaxon Oichnus simplex and are provisionally related to that trace fossil (Bromley 1981). The oval structures, however, are sufficiently characteristic as to deserve ichnotaxonomic separation on the basis of fossil material.

\section{Ichnogenus Oichnus Bromley 1981.}

Emended diagnosis: circular to subcircular holes of biogenic origin penetrating through skeletal substrates.

Discussion: the original diagnosis included pits having circular cross section that do not penetrate right through the substrate (Bromley 1981). These are particularly characteristic of echinoderm hosts and probably represent the work of parasites (e.g., Gale 1986), and have been separated as the ichnogenus Tremnichnus by Brett (1985). By so excluding these pits, the emended diagnosis of Oichnus is an improvement on the original.

\section{Oichnus ovalis isp. nov.}

Type material: Holotype: MGUH 22057, figure 5a. Paratype: MGUH 22058, figure 5b.

Locus typicus: the bay south of Cape Vagia and 1 $\mathrm{km}$ east of Kolymbia, Rhodes, Greece.

Stratum typicum: near the base of the yellow limestone unit that forms the foreshore of the bay: Upper Pliocene.

Diagnosis: oval Oichnus tapering subparabolically from a millimetre-sized external aperture to 

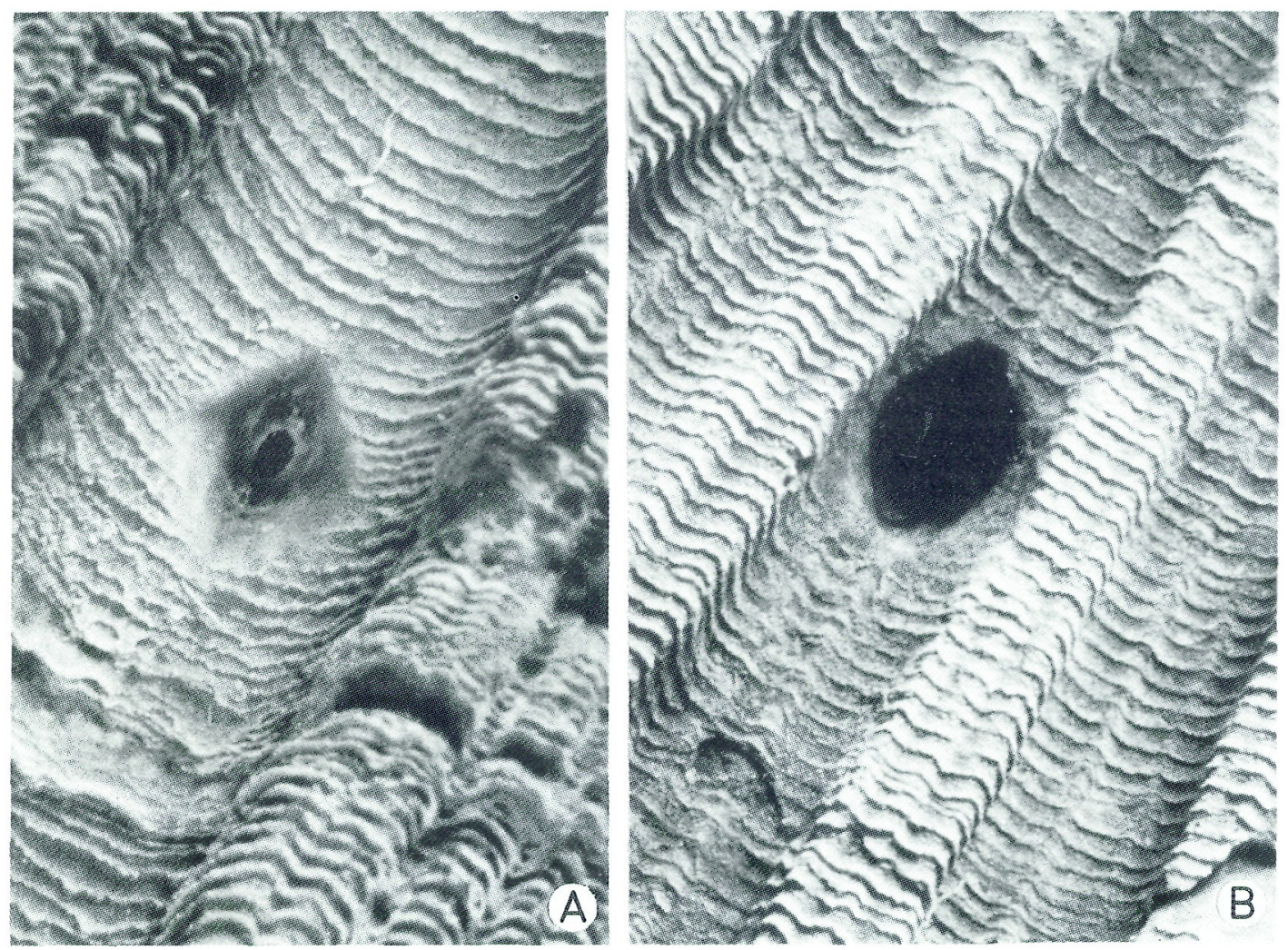

Fig. 5. A: Oichnus ovalis, holotype, in the flat valve of Pecten jacobaeus. $\times 15$. B: O. ovalis, paratype, in the flat valve of another individual of $P$. jacobaeus. $\times 15$. Same locality as holotype.

a minute inner one. External aperture commonly rhomboid in outline.

Description: the outer aperture may be sharp and crisp in outline, or in some cases rounded and softly contoured. It is normally elongatedly oval in shape but commonly has a somewhat rhomboid form. The sides of the hole converge inward in a curved manner that in cross section resembles a parabola, leading to a very small inner opening that is usually oval. Walls smooth. Unfinished examples are abundant, where complete penetration has not been achieved.

Interpretation: produced today by octopod cephalopods in skeletons of prey animals, particularly molluscs, including gastropod shells reused by hermit crabs, as well as brachyuran crab carapaces. In contrast to the more cylindrical forms mentioned above, the oval variety here named may represent examples where the octopus has not turned the prey while drilling it.
Remarks: oval drill-holes have been documented in shells of oyster spat today, being the work of a predatory polycladid (turbellarian) flatworm (Woelke 1957). Little is known of this activity, but it appears that although the holes are oval, they are not bevelled, and are on a much smaller scale than those produced by octopus.

Repository: material with MGUH numbers is deposited in the Geological Museum of the University of Copenhagen, Denmark.

\section{Palaeontological perspectives}

Those groups of organisms that are of the highest ecological significance today, and yet have no fossil record, are a constant embarrassment for the palaeontologist. The presumed forests of hydroids, demosponges and sea-weeds that covered seafloors of the past remain inferred but undocu- 
mented. Yet some of these organisms may have left recognizable signs of their existence through their life activities.

Trematode flatworms (flukes) represent such a group of important yet unpreserved animals. Yet an example was recently published (Ruiz \& Lindberg 1989) of recognizable trace fossils produced by trematodes in mollusc shells, and opening up a possibility of glimpsing the past history of at least some of these worms.

Considering its importance as top carnivore in recent marine communities, world wide, it is also embarrassing that the octopus is virtually unknown in the fossil record. As a "taphonomic loser", it is out of sight and therefore out of mind. Illogically, the octopus is never included in reconstructions of palaeocommunities.

The Pliocene molluscan faunas of Greece show borings identical to recent octopus drill-holes, similarly located on the shells of similar prey species. The trace fossils are not obvious; they require careful searching of shells having wellpreserved surfaces. Robba \& Ostinelli (1975) also described and illustrated octopus drill-holes from the Pliocene, in Italy. I am convinced that further search of earlier mollusc substrates will reveal older incidences of octopus predation. Engeser (1990) expressed similar optimism.

The borings of different species of octopods today are apparently indistinguishable. Do or did any other cephalopods have the ability to bore their prey? Were any ammonoids or belemnoids able to drill? Trace fossils may provide some answers to these questions.

Bond \& Sanders (1989) found traces of injuries and damage in Mississippean ammonoids that correspond closely to those in recent nautilus shells; they reported no drill-holes although modern nautilus shells commonly bear several octopod borings. Were these workers looking for them?

Tsudy et al. (1989) suggested we look for evidence of bite traces on fossil lobster exoskeletons that would correspond to the recent predilection of nautilus for shed skins of these crustaceans. They were pessimistic, however, about distinguishing such damage from physical damage.

Neat, oval drill-holes, however, are unmistakable. I am optimistic that they will provide testimony for the earlier history of the octopus and its gastronomic preferences.

\section{Dansk sammendrag}

På grund af manglende skeletmateriale er oktopus'er ganske ukendte fossilt. Deres store rolle i recente marine samfund antyder, at de alligevel må have haft en lang geologisk historie. Flere arter oktopus borer $i$ dag meget små huller $i$ deres byttes skelet. Nogle af disse huller har en rhombisk eller oval form og er genkendelige som sporfossiler. De er fundet i Pliocane skaller, og det forventes, at de vil blive fundet $i$ aldre tertiære, og måske endda mesozoiske molluskskaller. De karakteristiske borehuller er blevet navngivet Oichnus ovalis.

\section{References}

Ambrose, R. F. 1983: Midden formation by octopuses: the role of biotic and abiotic factors. Marine Behavior and Physiology 10, 137-144.

Ambrose, R. F., Leighton, B. J. \& Hartwick, E. B. 1988: Characterization of boreholes by Octopus dolfeini in the bivalve Saxidomus giganteus. Journal of Zoology, London 214, 491-503.

Arnold, J. M. 1985:- Shell growth, trauma, and repair as an indicator of life history for Nautilus. The Veliger 27, 386396.

Arnold, J. M. \& Arnold, K. O. 1969; Some aspects of holeboring predation by Octopus vulgaris. American Zoologist 9, 991-996.

Bond, P. N. \& Sanders, W. B. 1989: Sublethal injury and shell repair in Upper Mississippian ammonoids. Paleobiology $15,414-428$.

Boyle, P. R. \& Knobloch, D. 1981: Hole boring of crustacean prey by the octopus Eledone cirrhosa (Mollusca, Cephalopoda). Joumal of Zoology, London 193, 1-10.

Brett, C. E. 1985: Tremnichnus; a new ichnogenus of circularparabolic pits in fossil echinoderms. Journal of Paleontology 59, 625-635.

Bromley, R. G. 1970: Borings as trace fossils and Entobia cretacea Portlock, as an example. Geological Journal Special Issues 3, 49-90.

Bromley, R. G. 1981: Concepts in ichnotaxonomy illustrated by small round holes in shells. Acta Geológica Hispanica $16,55-64$.

Bromley, R. G. 1990: Trace fossils: biology and taphonomy. Unwin Hyman: London, $280 \mathrm{pp}$.

Bromley, R. G. \& Fürsich, F. T. 1980: Comments on the proposed ammendments to the International Code of Zoological Nomenclature regarding ichnotaxa. Bulletin of Zoological Nomenclature 37, 6-10.

Carriker, M. R. \& Yochelson, E. L. 1968: Recent gastropod boreholes and Ordovician cylindrical borings. United States Geological Survey Professional Papers 593-B, 26 pp.

Carter, R. M. 1968: On the biology and palaeontology of some predators of bivalved Mollusca. Palaeogeography. Palaeoclimatology. Palaeoecology 4, 29-65.

Donovan, D. T. 1964: Cephalopod phylogeny and classification. Cambridge Philosophical Society. Biological Reviews 39, 259-287.

Engeser, T. 1990: Phylogeny of the coleoid Cephalopoda (Mollusca). Berliner geowissenschaftlicher Abhandlungen (A) 124, 123-191.

Fujita, S. 1916: On the boring of pearl oysters by Octopus (Polypus) vulgaris Lamarck. Dobytsugaku Zasshi 28, 250257. (In Japanese: fide Nixon \& Maconnachie 1988.)

Gale, A. S. 1986: Goniasteridae (Asteroidea, Echinodermata) from the Late Cretaceous of north-west Europe. 1. Introduction. The genera Metopaster and Recurvaster. Mesozoic Research 1, 1-69. 
Guerra, A. \& Nixon, M. 1987: Crab and mollusc shell drilling by Octopus vulgaris (Mollusca: Cephalopoda) in the Ria de Vigo (north-west Spain). Journal of Zoology, London $211,515-523$.

Jeletzky, J. A. 1965: Taxonomy and phylogeny of fossil Coleoidea (= Dibranchiata). Geological Survey of Canada. Report of Activities (2) 65-2, 72-76.

Jeletzky, J. A. 1966: Comparative morphology, phylogeny, and classification of fossil Coleoidea. University of Kansas Paleontological Contributions, Mollusca 7, $192 \mathrm{pp}$.

Melville, R. V. 1979: Further proposed amendments to the International Code of Zoological Nomenclature Z.N. (G.) 182. Bulletin of Zoological Nomenclature 36, 11-14.

Nixon. M. 1977: Hole-boring by Octopus vulgaris Cuvier from the Mediterranean Sea. Abstracts 6th European Malacological Congress: $1 \mathrm{p}$.

Nixon, M. 1979a: Has Octopus vulgaris a second radula? Journal of Zoology, London 187, 291-296.

Nixon, M. 1979b; Hole-boring in shells by Octopus vulgaris Cuvier in the Mediterranean. Malacologia 18, 431-443.

Nixon, M. 1980. The salivary papilla of Octopus as an accessory radula for drilling shells. Journal of Zoology, London 190 , 53-57.

Nixon, M. \& Boyle, P. 1982: Hole-drilling in crustaceans by Eledone cirrhosa (Mollusca: Cephalopoda). Journal of Zoology, London 196, 439-444.

Nixon, M. \& Maconnachie, E. 1988: Drilling by Octopus vulgaris (Mollusca: Cephalopoda) in the Mediterranean. Journal of Zoology, London 216, 667-716.

Nixon, M., Maconnachie, E. \& Howell, P. G. T. 1980: The effects on shells of drilling by Octopus. Journal of Zoology, London 191, 75-88.

Pilson, M. E. Q. \& Taylor, P. B. 1961: Hole drilling by Octopus. Science 134, 1366-1368.
Robba, E. \& Ostinelli, F. 1975: Testimonianze di predazione sui molluschi pliocenici di Albenga. Rivista Italiana di Paleontologia e Stratigrafia 81, 309-372.

Roger, J. 1944: Phylogénie des céphalopodes octopodes: Palaeoctopus newboldi (Sowerby 1846) Woodward. Bulletin de la Société Géologique de France (5) 14, 83-98.

Roger, J. 1946: Les invertébrés des couches à poissons du Crétacé supérieur du Liban. Mémoire de la Société Géologique de France (n. S.) 23, 92 pp.

Ruiz, G. M. \& Lindberg, D. R. 1989: A fossil record for trematodes: extent and potential uses. Lethaia 22, 431-436.

Solem, A. \& Richardson, E. S. 1975: Paleocadmus, a nautiloid cephalopod radula from the Pennsylvanian Francis Creek Shale of Illinois. The Veliger 17, 233-242.

Teichert, C. 1967: Major features of cephalopod evolution. Essays in Paleontology and Stratigraphy. Raymond C. Moore Commemorative Volume. University of Kansas. Department of Geology Special Publication 2, 162-210.

Tshudy, D. M., Feldmann, R. M. \& Ward, P. D. 1989: Cephalopods: biasing agents in the preservation of lobsters. Journal of Paleontology 63, 621-626.

Wodinsky, J. 1969: Penetration of the shell and feeding on gastropods by Octopus. American Zoologist 9, 997-1010.

Woelke, C. E. 1957: The flatworm Pseudostylochus ostreophagus Hyman, a predator of oysters. Proceedings of the $\mathrm{Na}$ tional Shellfisheries Association, Washington 47, 62-67.

Woodward, H. 1896: On a fossil octopus (Calaïs Newboldi J. De C. Sby. MS.) from the Cretaceous of the Lebanon. Quarterly Journal of the Geological Society of London 52, 229-234.

Ziegelmeier, E. 1954: Beobachtungen über den Nahrungserwerb bei der Naticide Lunatia nitida Donovan (Gastropoda Prosobranchia). Helgoländers Wissenshaftliche Meeresuntersuchungen 5, 1-33. 